\title{
Seed Germination and Seedling Vigor of Magonia pubescens
}

\author{
Cárita Rodrigues de Aquino Arantes ${ }^{1}$ (D), Carmen Lúcia Ferreira Fava ${ }^{1}$ (D), \\ Elisangela Clarete Camili ${ }^{1}$ (D), Walcylene Lacerda Matos Pereira Scaramuzza ${ }^{1}$ (D) \\ ${ }^{1}$ Universidade Federal de Mato Grosso (UFMT), Cuiabá, MT, Brasil
}

\begin{abstract}
The timbó (Magonia pubescens A. St.-Hil.) is a tree species of the family Sapindaceae occurring naturally in the Cerrados of Central Brazil. The objective of this study is to verify the influence of seed size, pre-soaking time in water and seedling production containers in the development of timbó seedlings. The experiment was completely randomized with a $2 \times 3 \times 2$ factorial design (two seed sizes, three pre-soaking times in water and two seedling production containers) with four replicates composed of six containers, each containing one seed. Large seeds presented a better germination and a greater expressiveness of the characteristics evaluated in seedlings. The pre-soaking of seeds did not interfere with the final percentage of germination. However, it accelerated the germination process, favoring the formation of normal seedlings. The polyethylene bag favored base diameter, length and root fresh matter.
\end{abstract}

Keywords: Sapindaceae, species of natural occurrence, native plant. 


\section{INTRODUCTION}

Timbó or tingui (Magonia pubescens) belongs to the family Sapindaceae. It is a deciduous and heliophyte tree, selective xerophyte, typical of seasonal forests (Giotto et al., 2009). It can be found in Brazil in the states of Ceará, Minas Gerais, Goiás, Mato Grosso, Mato Grosso do Sul and São Paulo. The tree reaches up to $10 \mathrm{~m}$ high, with a laced canopy foliage. It flowers from July to September and fruits from August to November. In order to obtain seeds, fruits must be harvested from the tree when they initiate the opening and the spontaneous fall of seeds, or they must be collected from the ground right after the fall. Fruit ripening occurs almost simultaneously with the new flowering (Lorenzi, 2009).

The fruit is a globular, woody, light brown capsule, with 7 to $10 \mathrm{~cm}$ in diameter and several winged seeds up to $8 \mathrm{~cm}$ wide. One kilogram of seeds contains approximately 447 units (Silva, 2005). Seed dispersal is predominantly anemochorous (Paula \& Alves, 1997). Seeds are oleaginous and, therefore, used for the manufacture of soap and to compose dry floral arrangements (Lorenzi, 2009). They are rich in saponin and used for cleaning skin ulcers. The stem bark tea is used to treat wounds, and root bark is used as a tranquilizer (Guarim Neto \& Morais, 2003).

Because it is a species with several uses, it is commonly exploited by extractivism in natural populations. Therefore, it is necessary to investigate propagation techniques as a viable form of conservation of this species, seeking to minimize losses of biodiversity. According to Smiderle et al. (2015), the most effective way to reintroduce endangered species into the environment for conservation and commercial purposes is through seeds. One of the techniques that can be used to propagate this species through seeds is by classifying them by size aiming to standardize the emergence of seedlings and obtain others of a similar size (Carvalho \& Nakagawa, 2012).

Another technique, this time to maximize seed germination, is to pre-soak seeds in water aiming to initiate the metabolism earlier. Macedo et al. (2009) verified that the pre-soaking of timbó seeds in water for 24 hours provided a higher percentage of germination and produced seedlings that are more vigorous.
Considering the type of containers for seedling production, according to Antoniazzi et al. (2013), the size and shape of such containers affect the survival capacity of plants in the field. For the production of large seedlings, large polyethylene bags represent the best alternative because they provide a greater development for the plants. However, it has not been defined which of such containers is the most feasible for producing more vigorous timbó seedlings.

Thus, the objective of this work is to verify the influence of seed size, pre-soaking time in water before sowing, and the seedling production container on the development of timbó seedlings.

\section{MATERIALS AND METHODS}

Seeds of $M$. pubescens were obtained from ripe fruits collected from ten matrices in the region of Chapada dos Guimarães, MT (15³1'14" S, 5604'17” $\mathrm{W})$ using a pruning equipment. The fruits were taken to the Seed Laboratory of the Faculdade de Agronomia e Zootecnia of Universidade Federal de Mato Grosso, where the seeds were benefited.

After benefiting, the seeds were separated into two lots: small seeds and large seeds. Small seeds had dimensions of 35 to $50 \mathrm{~mm}$ in length and 64 to $93 \mathrm{~mm}$ in width; large seeds had dimensions of 51 to $63 \mathrm{~mm}$ in length and 94 to $108 \mathrm{~mm}$ in width. In the small seeds lot, the initial water content was $6.98 \%$; in the large seeds lot, it was $5.91 \%$. Before being used, the seeds were stored for six months in bags of Kraft paper $\left(40 \mathrm{~g} \mathrm{~m}^{2}\right)$ in a refrigerated chamber at $18 \pm 2{ }^{\circ} \mathrm{C}$ and relative humidity of $63 \pm 4 \%$. After this storage period, the water content was kept at 6.39 and $6.05 \%$ for small and large seeds, respectively.

The experiment was carried out in a seedling production greenhouse covered with a black screen with $30 \%$ shading. The experiment was completely randomized, with a $2 \times 3 \times 2$ factorial design (two seed sizes, three pre-soaking times in water and two seedling production containers) with four replicates. Each replicate was composed of six containers, each containing one seed, totaling 12 treatments and 48 experimental units.

The containers were $6 \times 19 \mathrm{~cm}$ tubes with 8 longitudinal internal friezes, and $10 \times 20 \mathrm{~cm}$ black polyethylene bags with lateral perforations. 
The pre-soaking times in water were 0,12 and 24 hours. Before immersion, the wings of seeds were removed using scissors.

At sowing, the seeds were placed on the surface of the substrate up to half their width. Thus, part of the seeds were outside of the substrate, which was a black soil + fine expanded vermiculite at the proportion of $1: 1$, moistened with the amount of water equivalent to $60 \%$ of the retention capacity (Brasil, 2009).

The black soil was composed of sand $\left(323 \mathrm{~g} \mathrm{~kg}^{-1}\right)$, silt $\left(139 \mathrm{~g} \mathrm{~kg}^{-1}\right)$ and clay $\left(538 \mathrm{~g} \mathrm{~kg}^{-1}\right)$ with the following chemical characteristics: $\mathrm{OM}=67.0 \mathrm{~g} \mathrm{dm}^{-3} ; \mathrm{pH} \mathrm{CaCl}_{2}=3.7$; $\mathrm{pH}$ water $=4.3 ; \mathrm{P}=1.2 \mathrm{mg} \mathrm{dm}^{-3} ; \mathrm{K}=40 \mathrm{mg} \mathrm{dm}^{-3}$;

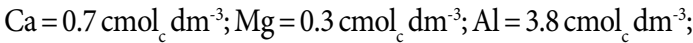
$\mathrm{CEC}=18.5 \mathrm{cmol}_{c} \mathrm{dm}^{-3}$; and $\mathrm{V}=6.0 \%$.

The containers were placed on the floor, and water replenishment was performed twice daily in the morning and in the late afternoon. The temperature and relative humidity were measured daily using a digital thermohygrometer, with temperatures ranging from 15.2 to $39.8^{\circ} \mathrm{C}$ and humidity from 31 to $99 \%$.

Evaluations to determine percentage and mean germination time (Maguire, 1962) and percentage and mean time of normal seedling formation were performed daily during a period of 30 days from sowing. We considered as a germinated seed those in which the emission of $2 \mathrm{~mm}$ of the epicotyl was observed, and as a seedling that had a well-developed shoot as those containing two definitive leaves.

Thirty days after sowing the seedling growth was evaluated in the laboratory by measuring the height using a graduated ruler from the base region to the point of insertion of the last leaf. The results were expressed in $\mathrm{cm}$ seedlings ${ }^{-1}$. The base diameter $\left(\mathrm{mm}\right.$ seedling ${ }^{-1}$ ) was measured using a digital caliper at the substrate level. The total number of leaves of each seedling, length of the longest root $(\mathrm{cm})$, and fresh and dry matter of shoot and root ( $\mathrm{g}$ seedling ${ }^{-1}$ ) were also obtained.

To determine the length of the longest root and the fresh and dry matter of shoot and root, the seedlings were delicately removed from the containers and the root system was washed until complete removal of the substrate. After washing, the seedlings were dried with a paper towel and, later, the shoot was separated from the root for weighing the fresh matter using a precision scale. In order to obtain the dry matter of the shoot and root, the material was packed in Kraft paper bags and put to dry in a forced-air circulation oven at $80^{\circ} \mathrm{C}$ for $24 \mathrm{~h}$. After drying, the material was removed from the greenhouse and the masses were obtained using a precision scale.

The data were submitted to analysis of variance $F(\alpha=0.05)$ and, when significant, the means were compared by Scott-Knott test ( $\alpha=0.05)$ using the SISVAR 5.3 software (Ferreira, 2010).

\section{RESULTS AND DISCUSSION}

Large seeds pre-soaked for 12 hours and seeded in a black polyethylene bag, and large seeds pre-soaked for 24 hours and seeded in the tube had a higher percentage of germination than small seeds under the same pre-soaking conditions and containers. According to Carvalho \& Nakagawa (2012), larger seeds of the same species have better formed embryos with more reserve substances, thus being more vigorous. However, considering the average germination percentage, it did not differ between seed sizes nor between container types.

The germination of small seeds was faster than large seeds when both were soaked for 24 hours and seeded in the tube (Table 1). According to Vanzolini \& Nakagawa (2007), generally smaller seeds germinate more quickly, but larger seeds provide more vigorous seedlings. Smiderle et al. (2015) observed that the percentage and germination rate of seeds of Euterpe oleracea were affected by size. Smaller seeds had less vigor.

The mean germination time decreased when the seeds were pre-soaked for 12 hours in both types of containers (Table 1). Carvalho \& Nakagawa (2012) reported that the process of water absorption causes the beginning of metabolic processes in seeds and a decrease in the resistance of the integument, favoring the emission of the radicle.

On average, seedlings grown from large seeds were higher than those grown from small seeds (Table 2). Kozlowski et al. (1991) reported that the growth in height of seedlings of different species occurs primarily using the carbohydrates stored in the seed. Thus, large seeds, because they have a greater amount of carbohydrate reserves, grow more in height when compared to small seeds.

The pre-soaking time influenced seedling height only when seeds were sown in the tube, and a lower value was observed when small seeds were pre-soaked 
Table 1. Percentage (\%) and mean germination time (MGT) of timbó seeds (Magonia pubescens) in function of container, seed size and pre-soaking time (hours). Cuiabá, MT, 2015.

\begin{tabular}{|c|c|c|c|c|c|c|c|}
\hline \multirow{3}{*}{ Container } & \multirow[b]{3}{*}{$\begin{array}{l}\text { Soaking } \\
\text { time }\end{array}$} & \multicolumn{3}{|c|}{ Germination (\%) } & \multicolumn{3}{|c|}{ MGT (days) } \\
\hline & & \multicolumn{3}{|c|}{ Seed size } & \multicolumn{3}{|c|}{ Seed size } \\
\hline & & Small & Large & $\begin{array}{c}\text { Average } \\
\text { germination }\end{array}$ & Small & Large & $\begin{array}{c}\text { Average } \\
\text { MGT }\end{array}$ \\
\hline \multirow{3}{*}{$\begin{array}{l}\text { Polyethylene } \\
\text { bag }\end{array}$} & 0 & $100 \mathrm{aA}^{\star}$ & $96 \mathrm{aA}$ & $98 \mathrm{~A}$ & $14.28 \mathrm{aC}$ & $13.58 \mathrm{aC}$ & $13.93 \mathrm{C}$ \\
\hline & 12 & $92 \mathrm{bB}$ & $100 \mathrm{aA}$ & $96 \mathrm{~A}$ & $8.80 \mathrm{aA}$ & 8.78 aA & $8.79 \mathrm{~A}$ \\
\hline & 24 & $96 \mathrm{aA}$ & $100 \mathrm{aA}$ & $98 \mathrm{~A}$ & $11.03 \mathrm{aB}$ & $11.25 \mathrm{aB}$ & $11.14 \mathrm{~B}$ \\
\hline \multirow[t]{2}{*}{ Mean } & & $96 a$ & $99 a$ & & $11.37 \mathrm{a}$ & $11.20 \mathrm{a}$ & \\
\hline & 0 & $100 \mathrm{aA}$ & $96 \mathrm{aA}$ & $98 \mathrm{~A}$ & $12.75 \mathrm{aB}$ & $13.50 \mathrm{aB}$ & $13.13 \mathrm{~B}$ \\
\hline \multirow[t]{2}{*}{ Tube } & 12 & $100 \mathrm{aA}$ & $100 \mathrm{aA}$ & $100 \mathrm{~A}$ & $10.38 \mathrm{aA}$ & $11.70 \mathrm{aA}$ & $11.04 \mathrm{~A}$ \\
\hline & 24 & $92 \mathrm{bA}$ & $100 \mathrm{aA}$ & $96 \mathrm{~A}$ & $11.03 \mathrm{aB}$ & $13.38 \mathrm{bB}$ & $12.20 \mathrm{~B}$ \\
\hline Mean & & $97 \mathrm{a}$ & $99 \mathrm{a}$ & & $11.38 \mathrm{a}$ & $12.86 \mathrm{a}$ & \\
\hline Mean size & & $96 \mathrm{a}$ & $99 a$ & & $11.38 \mathrm{a}$ & $12.03 \mathrm{a}$ & \\
\hline CV (\%) & & & & & & & \\
\hline
\end{tabular}

$\mathrm{CV}$ : coefficient of variation; ${ }^{*}$ means followed by lowercase letters on the same line and the same capital letters in the column within each container do not differ statistically from one another by Scott-Knott test $(p<0.05)$.

for 24 hours. Regarding the container, no differences were observed for the height of seedlings (Table 2). However, Bao et al. (2014) obtained a higher height of seedlings of Matayba guianensis when cultivated in the tube.

Large seeds formed seedlings with a larger base diameter than those grown from small seeds. According to Biruel et al. (2010), seedling vigor is directly related to seed size, which justifies the adoption of size classes for the production of seedlings. The pre-soaking time of seeds did not influence the seedling base diameter.

On average, seedlings produced in black polyethylene bags had a larger base diameter than those produced in tubes (Table 2). Bao et al. (2014) found that the highest base diameter values of $M$. guianensis seedlings were obtained from seedlings grown in tubes and polyethylene bags when compared to seedlings produced in polystyrene trays (Styrofoam). Antoniazzi et al. (2013), evaluating seeds of Cedrela fissilis, verified that the average base diameter was higher in seedlings produced in polyethylene bags, with values extremely superior to seedlings grown in tubes. In both works, Bao et al. (2014) and Antoniazzi et al. (2013) observed that the larger the diameter of the container, the greater the development of the seedling base.

The greater amount of seed reserve increases the possibility of success in the establishment of the seedling, since it allows its survival for a longer time in environmental conditions that still do not allow the use of nutritional and water reserves from the soil and the accomplishment of photosynthesis (Haig \& Westoby, 1991). In this work, seed size influenced the number of leaves per seedling. Large seeds provided seedlings with more leaves than seedlings originated from small seeds.

The container and the soaking time did not influence the number of leaves of seedlings (Table 3 ). Bao et al. (2014) also observed that the cultivation of M. guianensis in different containers did not affect the number of leaves of seedlings. However, Antoniazzi et al. (2013) found that the mean number of leaves of seedlings of C. fissilis was higher in seedlings produced in polyethylene bags compared to seedlings grown in tubes.

Seed size and soaking time did not influence root length. Seedlings produced in polyethylene bags had greater roots than seedlings produced in the tube (Table 3). According to Schwengberg et al. (2002), the root length is directly proportional to the size of the container. The authors obtained a longer root length of Prunus salicina seedlings when they were produced in polyethylene bags.

According to Antoniazzi et al. (2013), the average number of leaves was higher in seedlings of $C$. fissilis 
Table 2. Height $(\mathrm{cm})$ and base diameter $(\mathrm{mm})$ of timbó seedlings (Magonia pubescens) from large and small seeds subjected to different pre-soaking times (hours) produced in a black polyethylene bag or tube 30 days after sowing. Cuiabá, MT, 2015.

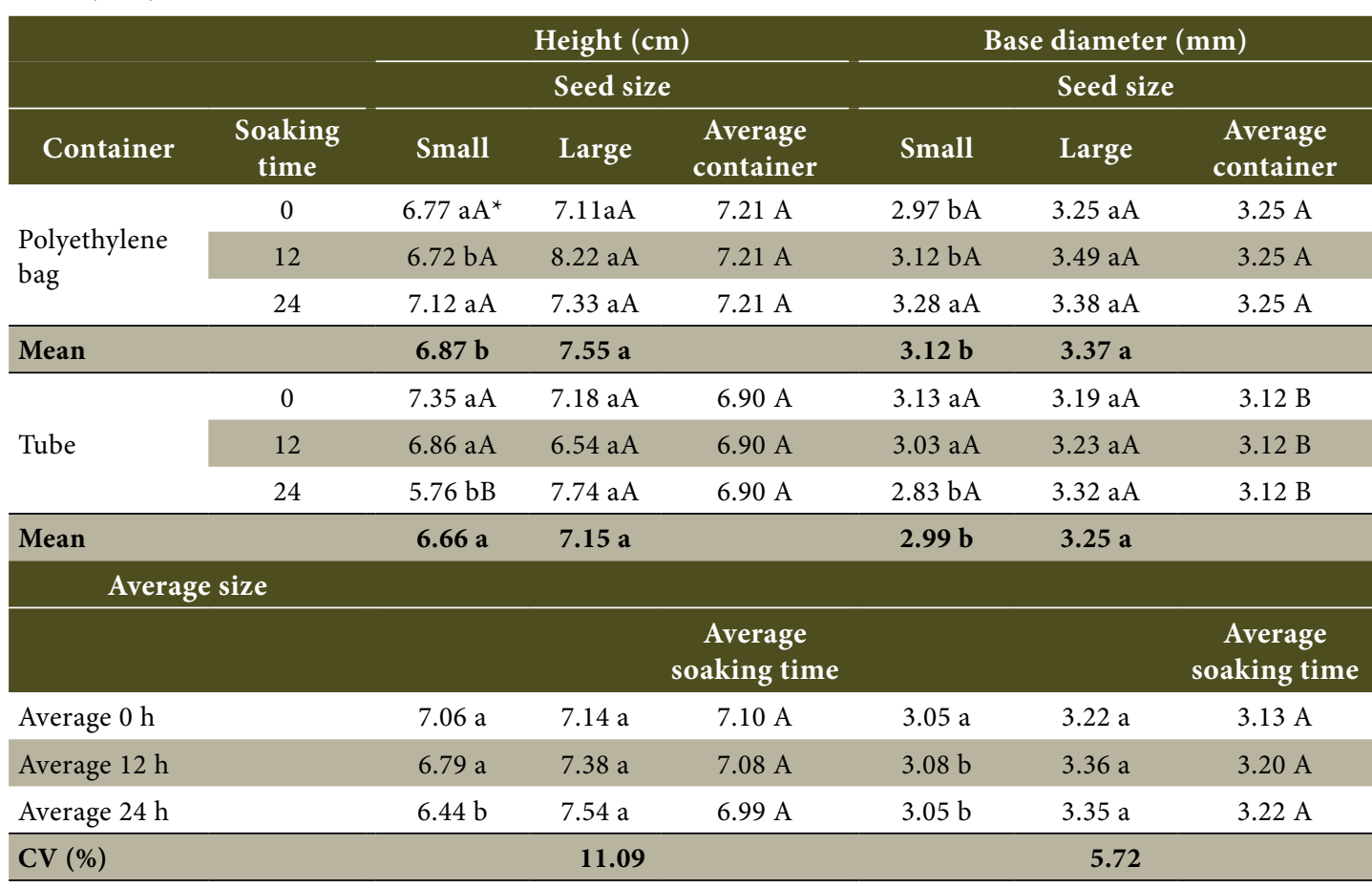

$\mathrm{CV}$ : coefficient of variation; ${ }^{\star}$ means followed by the same lowercase letters on the same line and the same capital letters in the column do not differ statistically from one another by Scott-Knott test $(p<0.05)$.

grown in polyethylene bags. Seedlings grown in tubes had lower values. However, Sturium et al. (2000) reported that the internal grooves of the tubes allow the alignment of the root system, causing a greater development. However, in this study, the radicle system was not favored by the inner grooves of the tube.

Bao et al. (2014) observed that the root length of $M$. guianensis was higher in seedlings cultivated in tubes compared to seedlings produced in polyethylene bags and Styrofoam trays. Thus, there is an interference of the container with the length of roots of seedlings, and it depends on the species.

Large seeds produced seedlings with a greater accumulation of fresh shoot matter in relation to small seeds. Moreira et al. (2016) reported that a greater amount of reserve of large seeds qualify them as easier to adapt and establish in the field, being less susceptible to post-germination stresses.

The pre-soaking of seeds favored the accumulation of shoot fresh matter independently of the period that it remained pre-soaking because the seeds that were pre-soaked germinated first, thus allowing more time to invest in growth. However, the container did not influence the fresh matter accumulation of seedlings (Table 4). This was expected because, in the first 30 days of seedling development, the mass accumulation occurs practically in function of the seed's reserves. The substrate is very important for water supply.

Seed size did not influence fresh root matter. However, the pre-soaking of seeds favored this characteristic, similar to shoots, regardless of the period that the seeds remained soaking (Table 4). This may have occurred because when seeds were pre-soaked they germinated faster. The seedlings grew more and developed larger roots. The polyethylene bag favored the accumulation of fresh root matter (Table 4 ) because seedlings produced in this container were larger than seedlings produced in the tube (Table 3).

Large seeds formed seedlings with a higher dry mass accumulation in shoots (Table 5), as well as a higher fresh shoot matter (Table 4). When the seeds were pre-soaked for 12 hours, it favored the accumulation 
Table 3. Number of leaves and length of the longest root $(\mathrm{cm})$ of timbó seedlings (Magonia pubescens) from large and small seeds subjected to different pre-soaking times (hours) produced in a black polyethylene bag or tube 30 days after sowing. Cuiabá, MT, 2015.

\begin{tabular}{|c|c|c|c|c|c|c|c|}
\hline \multirow{3}{*}{ Container } & \multirow[b]{3}{*}{$\begin{array}{c}\text { Soaking } \\
\text { time }\end{array}$} & \multicolumn{3}{|c|}{ Number of leaves } & \multicolumn{3}{|c|}{ Length of longest root $(\mathrm{cm})$} \\
\hline & & \multicolumn{3}{|c|}{ Seed size } & \multicolumn{3}{|c|}{ Seed size } \\
\hline & & Small & Large & $\begin{array}{l}\text { Average } \\
\text { container }\end{array}$ & Small & Large & $\begin{array}{c}\text { Average } \\
\text { container }\end{array}$ \\
\hline \multirow{3}{*}{$\begin{array}{c}\text { Polyethylene } \\
\text { bag }\end{array}$} & 0 & $2.25 \mathrm{aA}^{*}$ & $2.53 \mathrm{aA}$ & $2.36 \mathrm{~A}$ & $18.85 \mathrm{bB}$ & $21.23 \mathrm{aA}$ & $20.94 \mathrm{~A}$ \\
\hline & 12 & $2.15 \mathrm{bA}$ & $2.51 \mathrm{aA}$ & $2.36 \mathrm{~A}$ & $22.02 \mathrm{aA}$ & $22.05 \mathrm{aA}$ & $20.94 \mathrm{~A}$ \\
\hline & 24 & $2.32 \mathrm{aA}$ & $2.39 \mathrm{aA}$ & $2.36 \mathrm{~A}$ & $21.14 \mathrm{aA}$ & $20.35 \mathrm{aA}$ & $20.94 \mathrm{~A}$ \\
\hline Mean & & $2.24 \mathrm{~b}$ & $2.47 \mathrm{a}$ & & 20.67 a & $21.21 \mathrm{a}$ & \\
\hline \multirow{3}{*}{ Tube } & 0 & $2.13 \mathrm{aA}$ & $2.43 \mathrm{aA}$ & $2.27 \mathrm{~A}$ & $19.32 \mathrm{aA}$ & $18.68 \mathrm{aA}$ & $19.16 \mathrm{~B}$ \\
\hline & 12 & $2.34 \mathrm{aA}$ & $2.35 \mathrm{aA}$ & $2.27 \mathrm{~A}$ & $19.56 \mathrm{aA}$ & $19.25 \mathrm{aA}$ & $19.16 \mathrm{~B}$ \\
\hline & 24 & $2.09 \mathrm{aA}$ & $2.31 \mathrm{aA}$ & $2.27 \mathrm{~A}$ & $19.22 \mathrm{aA}$ & $18.95 \mathrm{aA}$ & $19.16 \mathrm{~B}$ \\
\hline Mean & & $2.18 \mathrm{a}$ & $2.36 \mathrm{a}$ & & 19.37 a & $18.96 \mathrm{a}$ & \\
\hline \multicolumn{8}{|c|}{ Average size } \\
\hline & & & & $\begin{array}{c}\text { Average } \\
\text { soaking time }\end{array}$ & & & $\begin{array}{c}\text { Average } \\
\text { soaking time }\end{array}$ \\
\hline Average $0 \mathrm{~h}$ & & $2.19 \mathrm{~b}$ & $2.48 \mathrm{a}$ & $2.33 \mathrm{~A}$ & $19.08 \mathrm{a}$ & $19.95 \mathrm{a}$ & $19.52 \mathrm{~A}$ \\
\hline Average $12 \mathrm{~h}$ & & $2.24 \mathrm{a}$ & $2.43 \mathrm{a}$ & $2.34 \mathrm{~A}$ & $20.79 a$ & $20.65 a$ & $20.72 \mathrm{~A}$ \\
\hline Average $24 \mathrm{~h}$ & & $2.20 \mathrm{a}$ & $2.35 \mathrm{a}$ & $2.28 \mathrm{~A}$ & $20.18 \mathrm{a}$ & $19.65 \mathrm{a}$ & $19.91 \mathrm{~A}$ \\
\hline CV (\%) & & & 9.52 & & & 9.04 & \\
\hline
\end{tabular}

$\mathrm{CV}$ : coefficient of variation; ${ }^{*}$ means followed by the same lowercase letters on the same line and the same capital letters in the column do not differ statistically from one another by Scott-Knott test $(p<0.05)$.

Table 4. Fresh matter of shoot and root (g) of timbó seedlings (Magonia pubescens) from large and small seeds subjected to different pre-soaking times (hours) produced in a black polyethylene bag or tube 30 days after sowing. Cuiabá, MT, 2015.

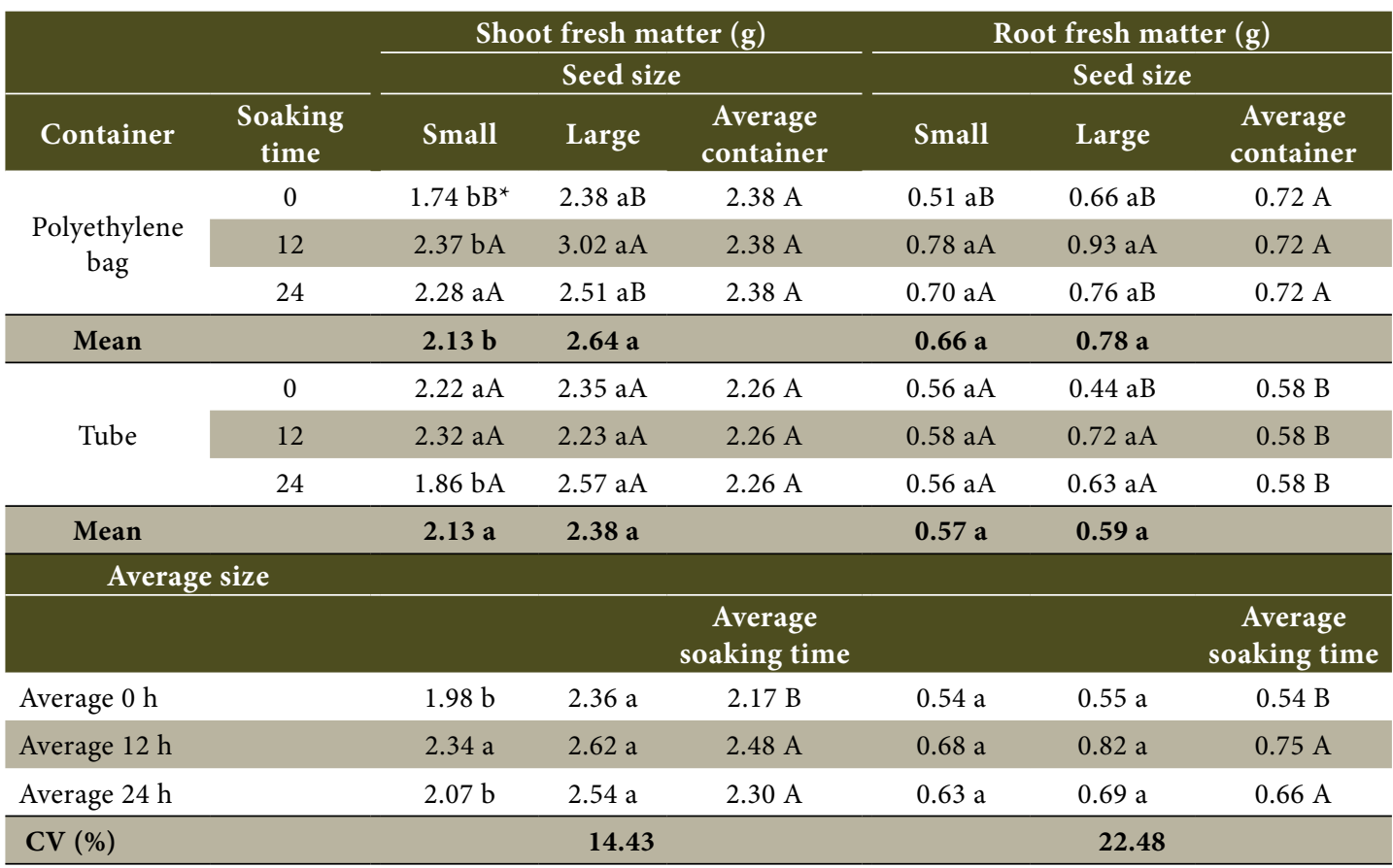

$\mathrm{CV}$ : coefficient of variation; ${ }^{*}$ means followed by the same lowercase letters on the same line and the same capital letters in the column do not differ statistically from one another by Scott-Knott test $(p<0.05)$. 
Table 5. Dry matter of shoot and root (g) of timbó seedlings (Magonia pubescens) from large and small seeds subjected to different pre-soaking times (hours) produced in a black polyethylene bag or tube 30 days after sowing. Cuiabá, MT, 2015.

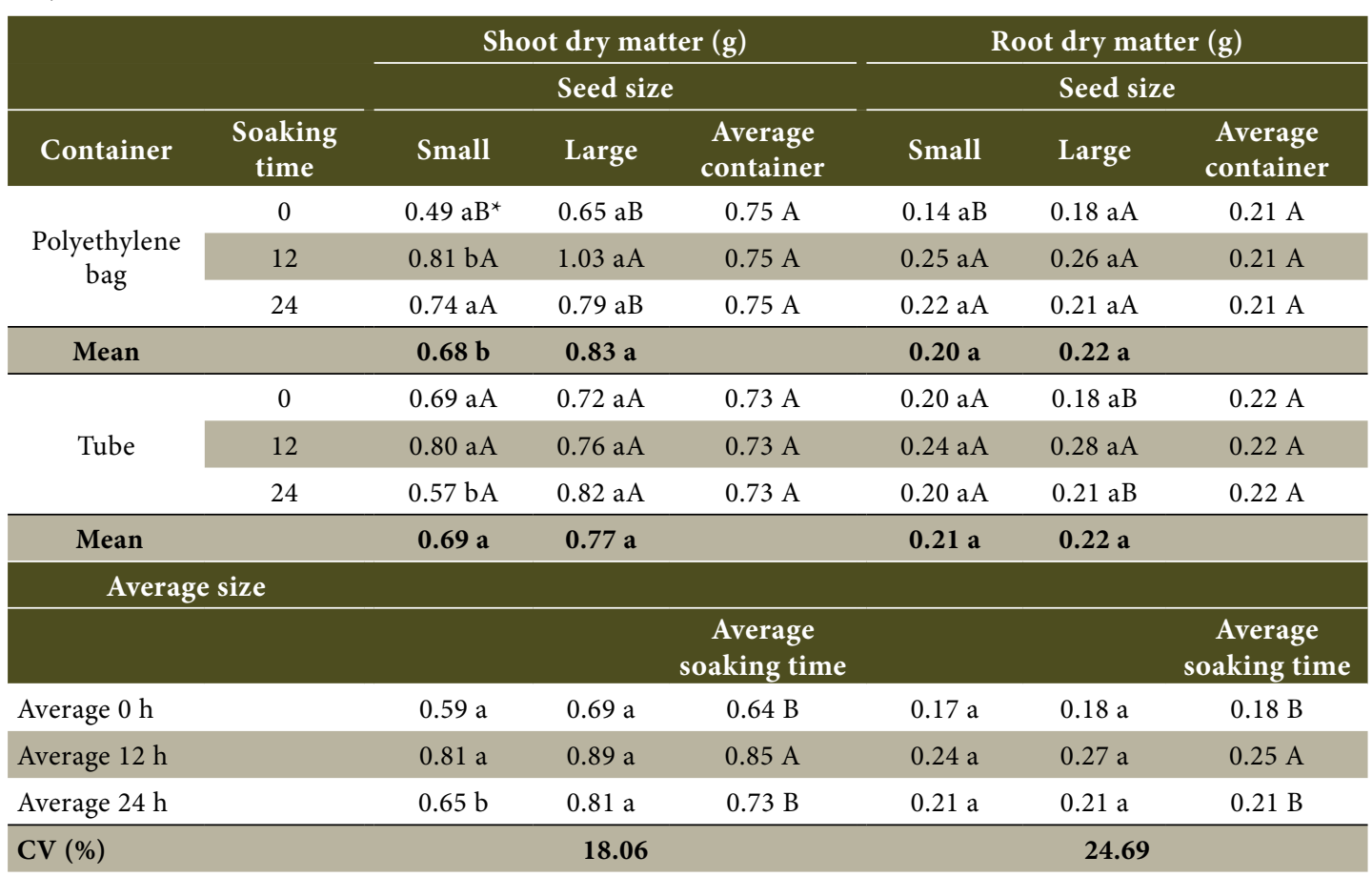

CV: coefficient of variation; ${ }^{*}$ means followed by the same lowercase letters on the same line and the same capital letters in the column do not differ statistically from one another by Scott-Knott test $(p<0.05)$.

of shoot dry matter of seedlings (Table 5). This result was directly proportional to the shoot fresh matter (Table 4) of plants originated from seeds that were pre-soaked for 12 hours.

The studied containers did not interfere with the shoot dry matter of seedlings (Table 5). However, Bao et al. (2014) verified that the seedlings of M. guianensis showed a greater accumulation of dry matter when cultivated in tubes. On the other hand, seedlings of C. fissilis grown in tubes had lower values of shoot dry matter when compared to seedlings produced in polyethylene bags (Antoniazzi et al., 2013).

Seeds soaked for 12 hours formed seedlings with a higher root dry matter accumulation. This result is directly related to fresh root matter data (Table 4). Seed size and container did not interfere with root dry matter (Table 5). Bao et al. (2014) verified that the roots of seedlings of $M$. guianensis showed a greater accumulation of dry matter when cultivated in tubes.

The root dry matter of the seedlings of $C$. fissilis was higher in seedlings grown in polyethylene bags
(Antoniazzi et al., 2013). According to Cunha et al. (2005), larger containers offer better conditions for seedling development, but they should be used only for species that are slow to develop and that need to stay for longer in the greenhouse.

\section{CONCLUSIONS}

Large seeds of $M$. pubescens have a better physiological quality and vigor, requiring hydration before sowing in order to maximize germination and seedling production.

The sowing of seeds of $M$. pubescens in polyethylene bags favored the expression of the characteristics base diameter, root length and root fresh matter.

\section{ACKNOWLEDGEMENTS}

To Conselho Nacional de Desenvolvimento Científico e Tecnológico ( $\mathrm{CNPq}$ ) for granting a master's degree scholarship to Cárita Rodrigues de Aquino Arantes. 


\section{SUBMISSION STATUS}

Received: 22 Nov., 2016.

Accepted: 11 July, 2018.

\section{CORRESPONDENCE TO}

\section{Cárita Rodrigues de Aquino Arantes}

Universidade Federal de Mato Grosso, Av.

Fernando Corrêa da Costa, 2.367, Boa Esperança, CEP 78060-900, Cuiabá, MT, Brasil

e-mail: carita.rodrigues@hotmail.com

\section{REFERENCES}

Antoniazzi AP, Binotto B, Neumann GM, Luisa ST, Budke JC. Eficiência de recipientes no desenvolvimento de mudas de Cedrela fissilis Vell. (Meliaceae). Revista Brasileira de Biociências 2013; 11(3): 313-317.

Bao F, Lima LB, Luz PB. Caracterização morfológica do ramo, sementes e plântulas de Matayba guianensis Aubl. e produção de mudas em diferentes recipientes e substratos. Revista Árvore 2014; 38(1): 63-71. 10.1590/ S0100-67622014000100006

Biruel RP, Paula RC, Aguiar IB. Germinação de sementes de Caesalpinia leiostachya (benth.) ducke (pau-ferro) classificadas pelo tamanho e pela forma. Revista Árvore 2010; 34(2): 197-204. 10.1590/S0100-67622010000200001

Brasil. Regras para análise de sementes. Brasília, DF: Ministério da Agricultura Pecuária e Abastecimento; 2009.

Carvalho NM, Nakagawa J. Sementes: ciência, tecnologia e produção. 5th ed. Jaboticabal: Funep; 2012.

Cunha AO, Andrade LA, Bruno RLA, Silva JAL, Souza VC. Efeitos de substratos e das dimensões dos recipientes na qualidade das mudas de Tabebuia impetiginosa (Mart. Ex D.C.) Standl. Revista Árvore 2005; 29(4): 507-516. 10.1590/S0100-67622005000400002

Ferreira DF. Sisvar: a computer statistical analysis system. Ciência e Agrotecnologia 2010; 35(6): 1039-1042. 10.1590/ S1413-70542011000600001

Giotto AC, Miranda FS, Munhoz CBR. Aspectos da germinação e crescimento de mudas de Magonia pubescens A. St. Hill. Cerne 2009; 15(1): 49-57.
Guarim Neto G, Morais RG. Recursos medicinais de espécies do Cerrado de Mato Grosso: um estudo bibliográfico. Acta Botânica Brasílica 2003; 17(4): 561 584. 10.1590/S0102-33062003000400009

Haig D, Westoby M. Seed size, pollination casts and angiosperm success. Evolutionary Ecology 1991; 5(2): 231-247.

Kozlowski T, Kramer PJ, Pallardy SG. The physiological ecology of woody plants. London: Academic Press; 1991.

Lorenzi H. Árvores brasileiras: manual de identificação e cultivo de plantas arbóreas do Brasil. 5th ed. Nova Odessa: Plantarum; 2009. v. 1.

Macedo MC, Scalon SPQ, Sari AP, Scalon Filho H, Rosa YBCJ, Robaina AD. Biometria de frutos e sementes e germinação de Magonia pubescens ST. Hil (sapindaceae). Revista Brasileira de Sementes 2009; 31(2): 202-211. 10.1590/S0101-31222009000200024

Maguire JD. Speed of germination: aid in selection and evaluation for seedling emergence and vigor. Crop Science 1962; 2(1): 176-177.

Moreira FJC, Silva MAP, Medeiros Filho S. Germinação e crescimento inicial de cajuí (Anacardium microcarpum Ducke) em função do tamanho das sementes e do tempo de embebição. Caderno de Cultura e Ciência 2016; 15(1): 19-28.

Paula JE, Alves JLH. Madeiras nativas: anatomia, dendrologia, dendrometria, produção e uso. Brasília, DF: Fundação Mokiti Okada; 1997.

Schwengberg JE, Dutra LF, Tonietto A, Kersten E. Utilização de diferentes recipientes na propagação de ameixeira através de estacas. Revista Brasileira de Fruticultura 2002; 24(1): 285-288. 10.1590/S010029452002000100064

Silva MC Jr. 100 árvores do Cerrado: guia de campo. Brasília, DF: Rede de Sementes do Cerrado; 2005.

Smiderle OJ, Silva VX, Souza AG, Chagas EA, Souza AG, Ribeiro MIG et al. Açai seedling production: effect of substrates and seeds size on germination and growth of seedlings. Journal of Advances in Agriculture 2015; 4(1): 316-323. 10.24297/jaa.v4i1.4300

Sturium JA, Graça LR, Antunes JBM. Produção de mudas de espécies de rápido crescimento por pequenos produtores. Colombo: Embrapa Florestas; 2000.

Vanzolini S, Nakagawa J. Testes de vigor baseados no desempenho de plântulas. Informativo Abrates 2007; 17(1-3): 76-83. 